\title{
BIOGENIC STRUCTURES OF UNIONIFORM BIVALVES IN WET-INTERDUNE DEPOSITS (LATE MIOCENE-EARLY PLIOCENE, ARGENTINA)
}

\author{
NOELIA B. CARMONA, ${ }^{1}$ JUAN JOSÉ PONCE, ${ }^{1}$ AND ANDREAS WETZEL ${ }^{2}$ \\ ${ }^{1}$ CONICET, Instituto de Investigación en Paleobiología y Geología, Universidad Nacional de Río Negro, General Roca. 8332, Rio Negro, Argentina \\ ${ }^{2}$ Geologisch-Paläontologisches Institut, Universität Basel, Bernoullistrasse 32, CH-4056 Basel, Switzerland \\ email:ncarmona@unrn.edu.ar
}

\begin{abstract}
Environmental changes within a Neogene coastal dune system are recorded by endobenthic unioniform bivalves that lived in muddy or sandy interdune pond sediments. These bivalves were suspension-filter feeders that formed dense, almost monospecific communities in the wet-interdune deposits of the continental intervals of the Río Negro Formation (late Miocene-early Pliocene). Activity of unioniform bivalves appears to be related to sediment type; resting and locomotion traces dominate in the muddy heterolithic facies, whereas equilibrium/escape structures prevail in the sand-dominated heterolithic facies. These traces characterize two scenarios of the wet-interdune development. First, during high and/or relatively stable water levels, bivalves colonized the muddy bottom and produced resting and locomotion traces. When water level dropped due to desiccation, biogenic structures were impacted by the formation of mud cracks and subsequently covered by sand delivered by migrating dunes. Second, in spite of dune migration, some interdune areas remained wet or flooded and, in response to sediment aggradation, the bivalves produced equilibrium or escape structures, depending on the thickness of eolian sand cover. Only the integration of ichnologic and sedimentologic observations allows deciphering the evolution of the Neogene wetinterdune system in such a detail.
\end{abstract}

\section{INTRODUCTION}

Bivalves constitute one of the most successful groups of burrowers through most of the Phanerozoic, being adapted to multiple modes of life in both marine and continental aquatic settings (Stanley 1968, 1970, 1972; Seilacher 1982, 1984; Mángano et al. 1998). Within the continental realm, unioniform bivalves dominate the benthic biomass in fluvial and marginallacustrine environments and form dense communities (Good 2004). In this paper the term 'Unioniformes' is used instead of the 'unionid', following the suggestion of Bogan and Roe (2008), in order to avoid confusion of whether unionid refers to the Order Unionoida or the Superfamily Unionoidea.

The fossil record of unioniformes extends back to the Upper Devonian (Bogan and Roe 2008), and modern representatives occur in freshwater settings of all continents except Antarctica (see Anderson 2014). Traditionally, these organisms have been considered mostly sessile, although several studies on modern unioniformes have documented their ability to produce lateral and vertical movements (Schwalb and Pusch 2007, and references therein). Unioniformes are suspension filter-feeding bivalves that bury themselves in muddy or sandy sediments (Good 2004). These bivalves have a highly protrusive wedge-foot that allows them to burrow efficiently within the substrate (McMahon and Bogan 2001). In addition, form and sculpture of the shells appear to be related to environmental conditions; shells are thinner and less sculptured in quiet settings with dominantly fine substrates, and thicker, more inflated and more sculptured in hydraulically agitated habitats (Watters 1994; McMahon and Bogan 2001). Some trace fossil taxa produced by unioniform bivalves were described and analyzed by Johnston and Hendy (2005), Pieńkowski and Uchman (2009), and Uchman et al. (2011), among others.
Abundant traces of unioniform bivalves occur in the upper continental member of the Mio-Pliocene Río Negro Formation. These bivalve traces are found in sediments that accumulated in temporary ponds between coastal dunes forming so-called wet-interdune deposits. The unioniform traces are readily identified as their producers are commonly preserved at the ends of their traces. Zavala and Freije (2001) recognized the occurrence of bivalve remains in this member, attributing the specimens to Unio diluvii and Chilina sp. In addition to detailed sedimentologic analyses, these trace fossils provide the exceptional opportunity to document changes in behavioral strategies used by the same organisms in response to environmental changes in these settings. The goals of the present paper are (1) to document and to describe the different traces produced by the unioniform bivalves; (2) to identify the environmental significance of these biogenic structures in relation to the facies in which they occur; and (3) to integrate both ichnologic and sedimentologic findings to decipher the environmental evolution of interdune depositional settings.

\section{STUDY AREA AND GEOLOGICAL SETTING}

The upper Miocene to lower Pliocene Río Negro Formation (Andreis 1965) extensively crops out in the northern region of Patagonia, Argentina, in particular along sea cliffs and river-cut valleys (Fig. 1A). Three unconformity-bounded members are distinguished within this formation (Zavala et al. 2000; Carmona et al. 2012; Fig. 1B). The lower member consists mostly of medium- to coarse-grained sandstones and mudstones formed in a coastal eolian setting characterized by large dunes and dry- or wet-interdune deposits. The middle member comprises sandstones with abundant bioclasts and dark gray mudstone intervals deposited in a shallow-marine environment; this member records a complete transgressive-regressive cycle that occurred during the Tortonian (late Miocene) (Zinsmeister et al. 1981; Zavala and Freije 2000; Zavala et al. 2000). The 


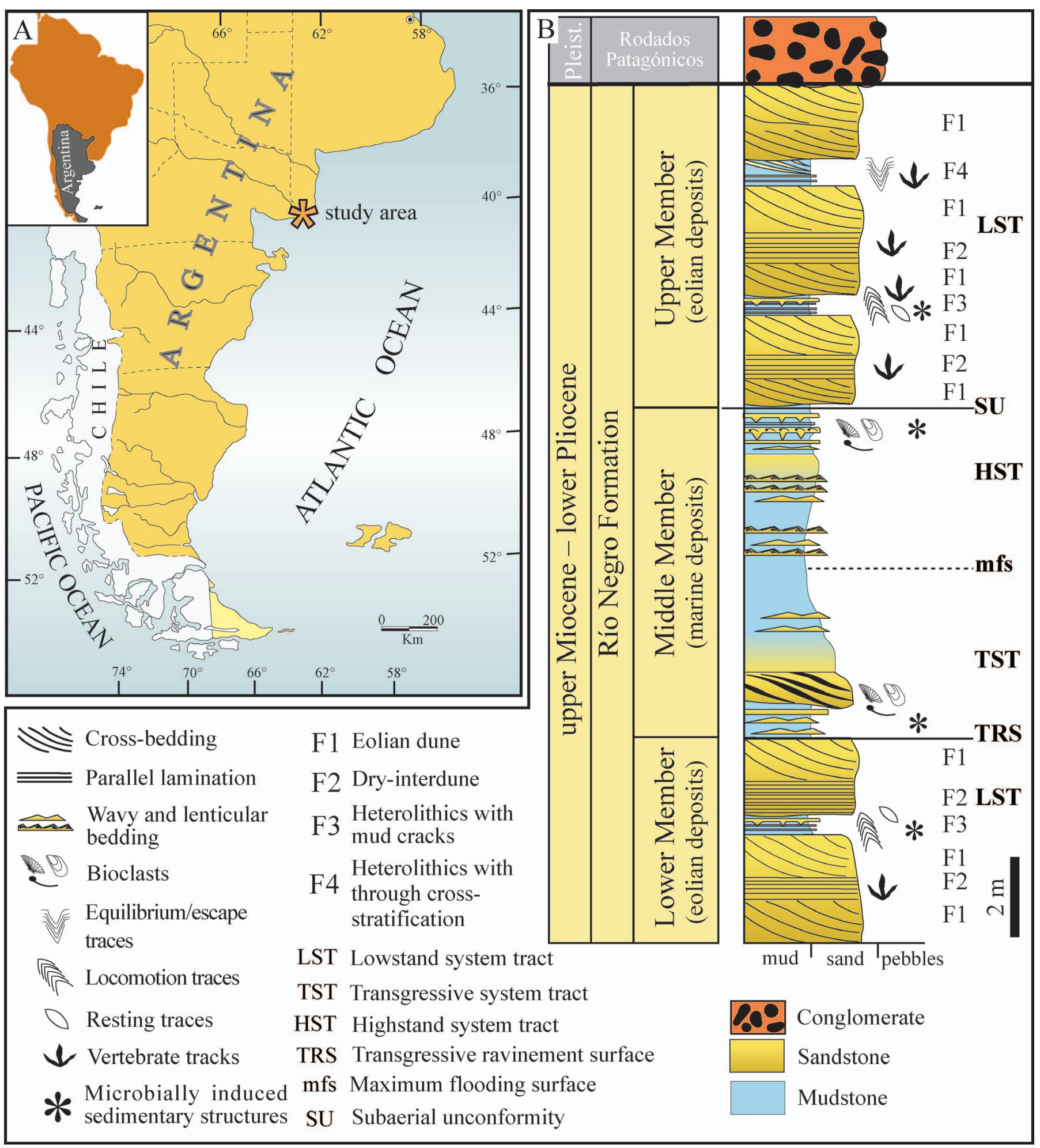

FIG. 1.- Location and stratigraphic context of the study. A) Map of the study area (marked with asterisk). B) Idealized stratigraphic section of the Rio Negro Formation showing dominant sedimentary facies. This study focused on the eolian deposits of the Upper Member.

upper member is mostly composed of sandstones. Its lower part accumulated in a coastal eolian setting similar to the lower member, while paleosols with carbonate nodules and tuff levels are intercalated towards the top of the member (Zavala and Freije 2000, 2001; Melchor 2009). Studies of mammal fossils and dating of the volcanic ash deposits indicate an early Pliocene age for the upper member (Aramayo 1987; Alberdi et al. 1997). This study addresses the continental dune and interdune deposits within the upper member, with a focus on wet-interdune and overlying dune facies (Fig. 1B). The analyzed outcrops are located along the Atlantic coast between Playa Bonita and El Faro. 
The facies relationships and paleogeographic reconstructions of the studied deposits of the Río Negro Formation suggest that the eolian system developed in close proximity to the Miocene-Pliocene Atlantic coast. The fossil vegetation in eastern Patagonia suggests that the dominant climate was arid and strongly seasonal during the Miocene. In contrast, during the Pliocene/Pleistocene, lower temperatures in the glacial periods and changes of precipitation gradients due to the rain shadow of the Andes led to increased aridity of this area (Iglesias et al. 2011).

\section{RESULTS}

\section{Sedimentology}

Based on several studied sections, a unified, synthetic lithologic log was compiled (Fig. 1B). Four lithofacies have been recognized in the studied interval: F1-medium- to fine-grained sandstone with large-scale trough cross-stratification, interpreted as eolian dune deposits; F2 - medium- to fine-grained sandstone with parallel lamination, interpreted as dry interdune sediments; F3 - mud-rich heterolithic deposits; and F4 - sandrich heterolithic sediments, both interpreted as wet-interdune deposits. Further characteristics of each facies are outlined in Table 1.

The bivalve traces occur preferentially in the wet-interdune deposits. Hence, the present analysis focuses mostly on F3 and F4, which comprise mud-dominated heterolithic sediments exhibiting lenticular bedding and laminated mud, and sand-dominated heterolithic deposits characterized by wavy and flaser bedding and tangentially cross-bedded sandstones, respectively. In the mud-dominated heterolithic intervals (F3), structures that can be related to microbial activity have been recognized, such as sponge pore fabric and shrinkage cracks, displaying the typical tri-radiate form and tapering ends (see Eriksson et al. 2007; Carmona et al. 2012).

\section{Ichnology}

Three different trace fossil types resulting from burrowing activity of unioniform bivalves have been recognized: (1) almond-shaped; (2) horizontal burrows with chevron-shaped margins; and (3) vertical Vshaped burrows having various extent.

Isolated Almond-Shaped Traces.-These traces occur in muddy heterolithic facies F3. They are the most abundant traces and comprise elongate, oval structures preserved on top of the muddy beds as negative epireliefs. In some levels, however, they occur as positive hyporeliefs at mud-sand interfaces (Fig. 2A, 2B). In horizontal section, they are $3-5.3 \mathrm{~cm}$ long and $1.6-3.1 \mathrm{~cm}$ wide. Penetration depth varies between $0.5-2.0 \mathrm{~cm}$, but very shallow burrows prevail. A longitudinal median ridge is observed in some specimens. One specimen, preserved as positive hyporelief, exhibits a faint longitudinal ornamentation (Fig. 2B).

These specimens are assigned to the ichnogenus Lockeia James 1879, which has been commonly interpreted as a resting trace (Seilacher 1953; Osgood 1970; Rindsberg 1994; Mángano et al. 2002), although some specimens may represent semi-permanent domiciles (Mángano et al. 2002). The faint ornamentation observed on burrow walls may correspond to the trace of the foot, as modern unioniformes have been observed usually resting with the foot extended (Johnston and Hendy 2005). This ichnogenus has been commonly described from both shallow and deep marine settings (see Mángano et al. 2002, and references therein). In addition, Lockeia occurs in continental settings (Bromley and Asgaard 1979; Głuszek 1995). According to the morphological features observed in these specimens, they are assigned to Lockeia siliquaria (James 1879), which is the most widespread ichnospecies. This ichnospecies is oval to almond-shaped, although it may display irregular outlines, typically tapers only at one end (the other end usually being rounded), and the surface is commonly smooth, although some corrugation can be observed (Mángano et al. 2002). Mángano et al. (2002) indicates that L. siliquiaria represents dwelling structures of suspension feeders or escape traces. In the studied material, some specimens are connected to locomotion structures and thus represent temporary resting traces.

Horizontal Traces with Chevron-Shaped Margins.-These traces occur in muddy heterolithic facies F3. When completely preserved, they exhibit an elongated central channel with short "chevron" marks on either side and almond-shaped elements at one or both terminal tips (Fig. 2C). In most cases, however, only the central channel is observed (Fig. 2D, 2E), and chevron marks are ill-defined. The width of central channels is approximately $0.4 \mathrm{~cm}$ and lengths vary from 2 to $15 \mathrm{~cm}$. In horizontal section, the terminal almond-shaped components are $2.9-4.2 \mathrm{~cm}$ long and $1.1-2.1 \mathrm{~cm}$ wide.

The elongate traces are interpreted as locomotion structures of the unioniform bivalves. Their burrow morphology is closely related to the shape and the work of their foot (Uchman et al. 2011). Recent studies have addressed the taxonomy of locomotion trace fossils produced by bivalves with a wedge-shaped foot, in particular the ichnogenera Ptychoplasma Fenton and Fenton 1937, and Oravaichnium Plička and Uhrová 1990 (Pieńkowski and Uchman 2009; Uchman et al. 2011). In positive hyporelief preservation, the ichnogenus Ptychoplasma comprises specimens having smooth, undulating, continuous to discontinuous subhorizontal ridges that are amygdaloid, carinate, or blocky in cross-section. In contrast, Oravaichnus exhibits smooth, irregularly meandering, winding or looping continuous ridges having box-like cross-sections (Uchman et al. 2011). Although all the locomotion traces observed in the Río Negro Formation are preserved as epichnial and endichnial structures, they most closely match the diagnosis of Ptychoplasma, particularly the ichnospecies P. excelsum. Ptychoplasma excelsum, the type ichnospecies, comprises amygdaloid bodies that overlap or are connected to form a continuous series (Uchman et al. 2011). The well-preserved specimens recorded in the Río Negro Formation, representing elongate burrow parts connecting almond-shaped traces, are included in this ichnospecies (Fig. 2D, 2E). Notably, the almond-shaped components of these specimens are slightly larger than the associated Lockeia.

Vertical V-Shaped Burrows.-These traces occur in heterolithic, mainly sandy facies F4. They consist of vertical to slightly oblique, V-shaped alternating sandy and muddy laminae, produced during the upward movement of unioniform bivalves. Vertical extent varies from 2 to $24 \mathrm{~cm}$. Two groups can be distinguished with respect to their vertical extent. Short traces are commonly 2 to $5 \mathrm{~cm}$ deep and have neat margins (Fig. 3A, 3B), whereas long burrows are 7 to $24 \mathrm{~cm}$ in vertical extent and exhibit irregular and convolute boundaries (Fig. 3C-3E). Bivalve producers are commonly preserved at the tops of these structures (Fig. 3F). Preservation of these specimens is restricted to vertical sections; bedding-plane views were not available.

These structures are interpreted as equilibrium/escape traces of unioniform bivalves. The short traces $(2-5 \mathrm{~cm})$ are interpreted as minor re-adjustments of the bivalve when small amounts of sediments entered the system. Longer and more disordered structures $(7-24 \mathrm{~cm})$ are interpreted to represent escape traces that indicate more substantial depositional events. These specimens resemble burrows assigned to Conichnus conicus Männil 1966 in their subvertical orientation and in having an internal convex-down structure (Knaust 2017). However, the specimens from the Río Negro Formation do not exhibit the typical plug-shaped morphology of this ichnospecies.

\section{DISCUSSION}

\section{Paleoecological Implications}

In order to fully understand the environmental significance of these bivalve traces, it is important to consider the ecology of modern 
TABLE 1.-Description and interpretation of facies.

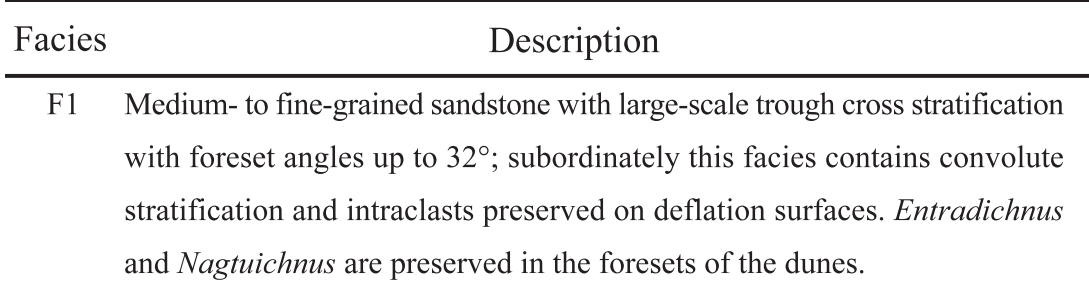

F2 Medium- to fine-grained sandstone with parallel lamination. In some cases, parallel lamination is associated with adhesion ripple strata, which are characterized by low-relief ridges showing upwind migration. The ichnologic assemblage is dominated by mammal and bird tracks.

F3 Mud-rich heterolithic units, displaying an alternation of laminated mud and sand with current and wave ripples. These deposits are lenticular in geometry. Desiccation cracks are common, and subordinate microbially induced sedimentary structures are present. The ichnologic assemblage is dominated by unioniform resting and locomotion traces, but subordinate rhizoliths and vertebrate tracks are also observed.

F4 Sand-rich heterolithic units, with a cm-scale alternation of laminated mud, and sand with current and wave ripples. The geometry of these deposits is lenticular, and sandstone with tangential cross bedding and mud drapes is common in the marginal areas of these lenticular bodies. The ichnologic assemblage is dominated by unioniform escape and equilibrium traces, and subordinate rhizoliths and vertebrate tracks are observed.
Interpretation

Figure

Eolian dunes

with deflation

surface

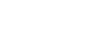

(2)

然

Dry interdune

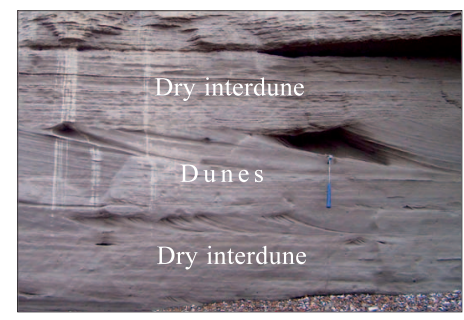

\section{Mud-dominated heterolithic wet} interdune

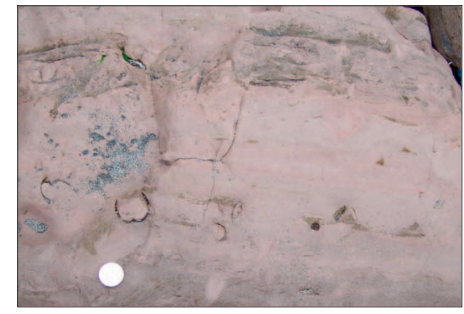

Sand-dominated heterolithic wet interdune

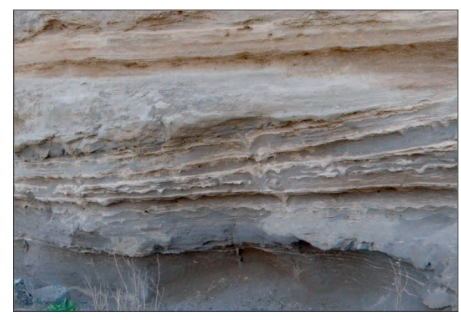

unioniformes. Filter-feeding bivalves constitute one of the most important macrofaunal groups in freshwater settings. In addition, they have the potential to influence the ecosystem structure in several ways. For example, they may provide substrates for epibionts and refuge for prey, alter the hydraulic flow characteristics, and link the water column and benthic zones as they are suspension feeders (Vaughn and Hakenkamp 2001; Schwalb and Pusch 2007; Bogan and Roe 2008). Unioniformes cannot dig very deeply because of their short siphons (McMahon 1991; Saarinen and Taskinen 2003). Typically they occupy an interval just below the watersediment interface or their posterior valve margins with the siphonal apertures protrude slightly above the interface (Trueman 1968; McMahon and Bogan 2001; Saarinen and Taskinen 2003). Good (2004) summarized the ecological requirements for unioniform bivalves, including low turbidity, well-oxygenated and shallow water, $\mathrm{pH}$ slightly greater than 7 , at least seasonally warm water, stable substrates, and abundant plankton for filter feeding. Considering the great abundance of unioniform traces in the Rio Negro Formation, it is likely that this bivalve population had a significant impact on the rest of this Miocene-Pliocene freshwater community.

Unioniformes employ the "push-and-pull" mechanism for locomotion (see Trueman 1968), which involves rhythmic changes in foot shape. Living close to the sediment-water interface makes these bivalves vulnerable to exhumation and transport by currents, so they are highly adapted to rapidly relocate themselves. Notably, pedal locomotion is more common in juveniles, which allows them to explore ecologically improved settings or to move to less densely populated areas (McMahon and Bohan 2001). Saarinen and Taskinen (2003 and references therein) summarize other hypotheses invoked to explain the locomotion of bivalves. These involve responses to unfavorable ecological conditions, such as food or oxygen deficiency, reproductive

FIG. 2.-Unioniform resting and locomotion trace fossils. A) Bedding plane view with numerous resting traces, assigned to Lockeia siliquiaria. B) Resting traces preserved as positive hyporeliefs; white arrow marks a specimen with faint longitudinal ornamentation. C) Locomotion traces assigned to Ptychoplasma excelsum. The elongate structure that connects the almond-shaped traces comprises a thin, central channel and short "chevron" marks on both sides (white arrow). D, E) Common preservation of the locomotion traces, which consist of a simple and thin elongate channel that connects almond-shaped structures, generally located at its terminal tips. 

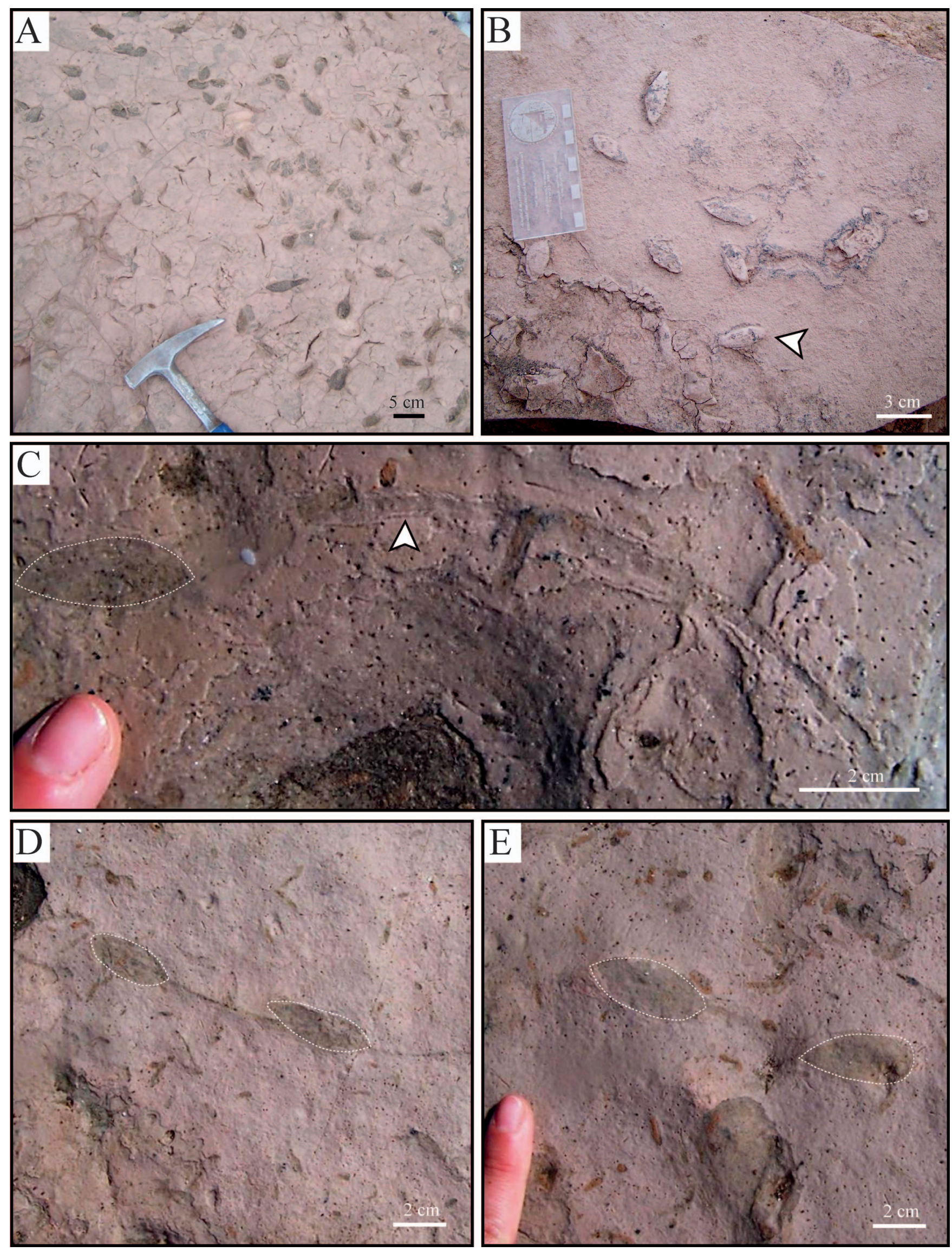

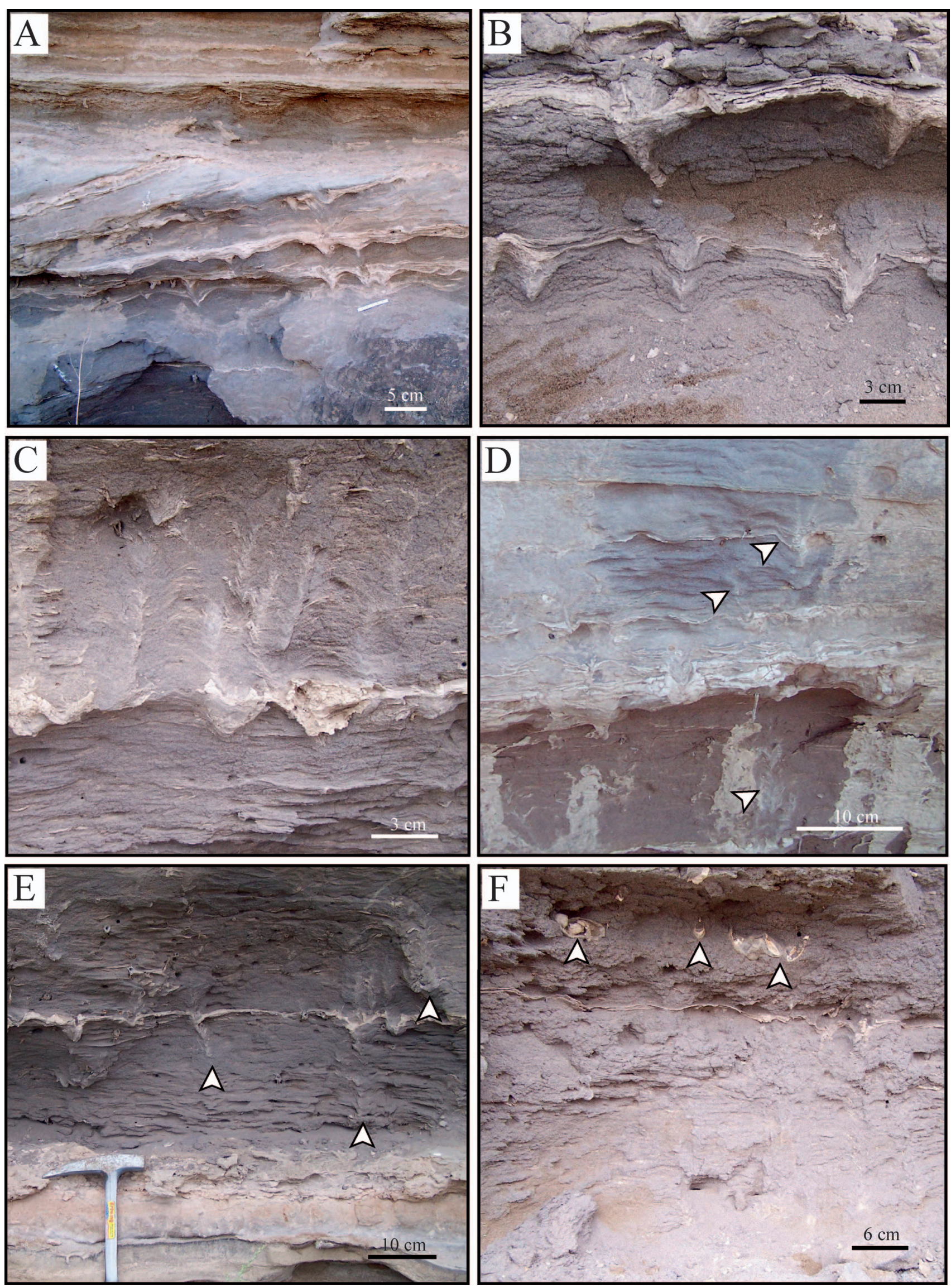

FIg. 3.-Unioniform equilibrium/escape traces. A, B) Equilibrium traces. C-E) Escape traces. White arrows in D and E indicate the escape structures. F) Bivalve producers partly preserved at the upper end of the structures (white arrows). 
purposes, pedal feeding on organic material, or behavioral anomalies produced by the presence of parasites. Of course, most of these hypotheses are difficult to test in the rock record by the analysis of trace fossils because much information is lost due to erosion, nondeposition or non-preservation.

If locomotion was a strategy to avoid spatial competition in the studied deposits, one would expect that the resting trace Lockeia would differ in size from the almond-shaped parts of the locomotion trace Ptychoplasma; the latter would correspond to juvenile producers and thus, should be smaller than the resting burrows of adult specimens. Although a small difference in size was observed between these two traces, it does not seem to be significant enough to support this hypothesis. Rather, all of the traces were most likely produced by bivalves of similar ontogenetic age. Furthermore, small differences in trace size may be related to variations in the positions of bivalve shells and feet within the substrate while moving or resting, rather than overall bivalve size. If locomotion had a reproductive meaning, locomotion traces should converge, reflecting the gathering of bivalves during spawning periods in lentic systems (see Amyot and Downing 1998). However, locomotion traces in the interdune deposits are isolated and not very abundant. Thus, the observed locomotion traces may simply reflect the bivalves' efforts to search for better local ecological conditions, such as currents or food.

Recent studies have documented that some adult unioniformes have the ability to move vertically. They bury themselves in order to reduce the risk of dislodgment due to eroding river currents at high discharge or to avoid severe cold during winter, and they emerge to the sediment surface during the reproductive periods, when water temperature rises or duration of daylight increases (Balfour and Smock 1995; Watters et al. 2001; Schwalb and Pusch 2007). Knoll et al. (2017) analyzed the escape capacity of two modern unioniform bivalves in relation to sediment grain size and depth of burial. Although there are some differences in the response of each species, in both cases the escape capability decreases as burial depth increases. A sediment cover thicker than approximately $10 \mathrm{~cm}$ appears to minimize chances for successful escape (Knoll et al. 2017). In the studied wet interdune deposits, the vertical upward movement recorded by the traces most likely indicates that the bivalves tried to prevent burial during periods of enhanced sediment deposition. They produced equilibrium traces when the sediment input was relatively small (only a few $\mathrm{cm}$ burial) and generated escape traces in response to considerable sedimentation, probably when approaching the threshold value of $10 \mathrm{~cm}$ found by Knoll et al. (2017).

Other studies have described traces attributed to upward escape movement of bivalves from anastrophic burial. In particular, Thoms and Berg (1985) analyzed very well-preserved escape traces attributed to Archanodon catskillensis from fluvial deposits of the Late Devonian Catskill Formation, eastern U.S.A., and compared them to recent burrows of Margaritifera margaritifera. These traces are comparable to the specimens in the Río Negro Formation. However, they are much more regular both in internal and external morphology and exhibit a basal curvature, features that are not observed in the equilibrium/escape traces analyzed here.

\section{Environmental Implications}

The studied interval has been interpreted as a coastal dune system that formed close to the sea during late Miocene-Pliocene times (Zavala and Freije 2000; Zavala et al. 2000). In particular, the upper member formed during rapid sea-level fall, with the subsequent progradation of eolian environments into the inner areas of the basin (Zavala and Freije 2000; see discussion in Carmona et al. 2012). Since the Oligocene, eustatic sea-level falls may be related to the growing ice sheets during glacial periods (Haq et al. 1987), in particular during the late Miocene when glaciation of the northern hemisphere became significant (e.g., Zachos et al. 2001). In spite of falling sea-level, wet, even flooded interdune areas developed when basin subsidence at least temporarily exceeded sea-level fall. At these times, freshwater bodies of the wet interdune facies formed in low areas where the water table exceeded the depositional surface and when sediment supply was moderate (Zavala and Freije, 2001). At the end of a wet phase, eolian and dry interdune facies commonly prograded over the wet interdune facies (Zavala and Freije, 2001).

Integration of both ichnologic and sedimentologic findings suggests two main scenarios for the environmental evolution of the wet-interdune settings: Case 1 is characterized by a fluctuating water table (Fig. 4), and Case 2 by considerable sediment supply from migrating dunes adjacent to the wet areas (Fig. 5). During the first stage, in both cases, bivalves colonized the muddy bottom of interdune ponds when the water levels were high and relatively stable (Figs. 4A, 5A, upper scheme and $t_{1}$ ). This stage is characterized by the production of abundant resting and locomotion traces (Fig. 2).

The second stage differs between cases. In Case 1, resting and locomotion traces occur in association with desiccation and shrinkage cracks and imply that water levels dropped and the previously wet interdune area desiccated (Fig. 4A ( $\left.\mathrm{t}_{2}\right)$, Fig. 4C, 4D). As the overlying dune deposits are not reworked by bivalves, the sediments evidently accumulated once the interdune area was already dry (Fig. 4A $\left.\left(\mathrm{t}_{3}\right)\right)$. In contrast, in Case 2, water level remained constant or perhaps was elevated, but the sediment supply from migrating dunes was higher than in Case 1. This is recorded by the resting traces in the muddy facies that occur in association with equilibrium/escape structures within the sandy facies above it (Fig. $5 \mathrm{~A}\left(\mathrm{t}_{2}\right)$, Fig. 5B). Evidently, the bivalves tried to keep pace with the considerable sand input from adjacent dunes and produced characteristic V-shaped equilibrium or escape traces in response to deposition of thin or thick eolian sand layers, respectively. Obviously, the unioniformes produced escape or equilibrium traces during dune migration (Fig. 5A $\left(t_{3}\right)$, Fig. 5C, 5D).

The water level within the coastal wet-interdune setting most likely was also influenced by variations in sea level. A similar situation was described for the Jurassic Entrada Sandstone in the western United States (Crabaugh and Kocurek 1993). High sea-level limited seaward groundwater drainage and, hence, favored the formation of interdune ponds. In contrast, low sealevel led to efficient drainage of coastal dune areas and prevalence of dry deposits. In both cases, interdune areas were later filled/covered by eolian sand. Consequently, trace fossils represent sensitive indicators to unravel the paleoenvironmental setting in detail.

\section{CONCLUSIONS}

The high density of bivalve locomotion, resting, and equilibrium/escape trace fossils at several localities of the Rio Negro Formation indicates that unioniform bivalves were ubiquitous members of these Miocene-Pliocene wet interdune freshwater biotas. The resting traces, assigned to Lockeia siliquaria, and the locomotion trails ascribed to Ptychoplasma excelsum are recorded on the muddy heterolithic facies, whereas the equilibrium/ escape trace fossils occur in the sandy heterolithic facies.

The trace fossils formed by unioniform bivalves and the deposits in which they occur are useful to differentiate two scenarios for the development of the wet-interdune setting: 1 , interdune ponds desiccated before migrating dunes covered the interdune areas, as evidenced by resting and locomotion traces in association with desiccation cracks; and 2, dunes progressively delivered considerable amounts of sand to still flooded, wet-interdune areas, but the ponds persisted and resting traces were formed in association with equilibrium/escape traces. Deciphering such environmental changes within the coastal dune area was possible only through the integration of both ichnologic and sedimentologic observations. Additional studies on equivalent settings that include the trace fossil 

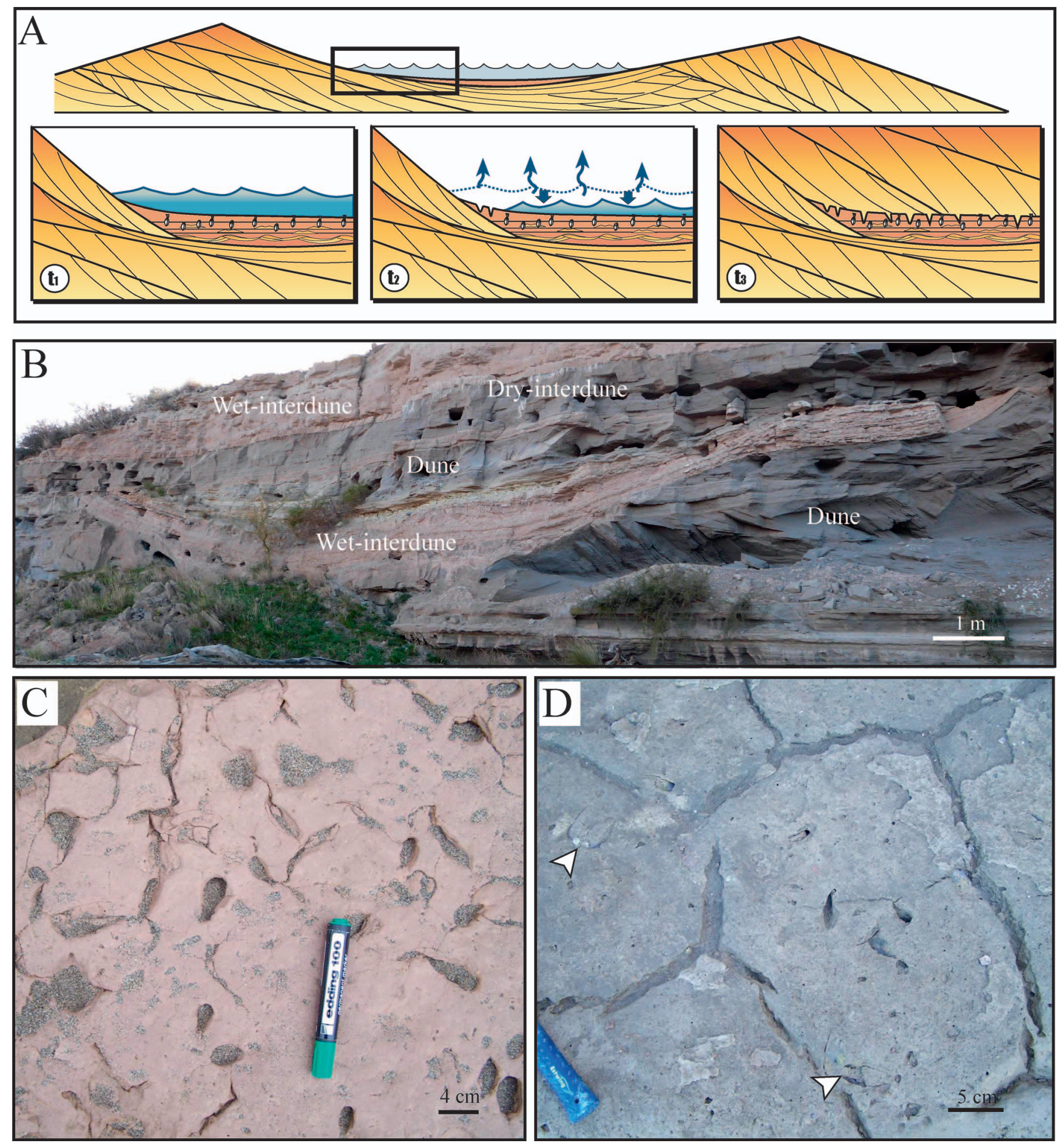

FIG. 4. - Case 1 interpretation: desiccation of interdune pond. A) Upper scheme showing general configuration of the setting; $t_{1}$ - bivalves colonize muddy heterolithic sediment, $\mathrm{t}_{2}$ - water level drops, $\mathrm{t}_{3}$ - after complete desiccation, muddy levels are covered by dune deposits. Note that the unioniform traces are confined to muddy intervals. B) Outcrop view showing the relationship between wet and dry interdune and dune deposits. C, D) Plane view with unioniform resting traces and desiccation cracks (white arrows in D mark unioniform molds). 

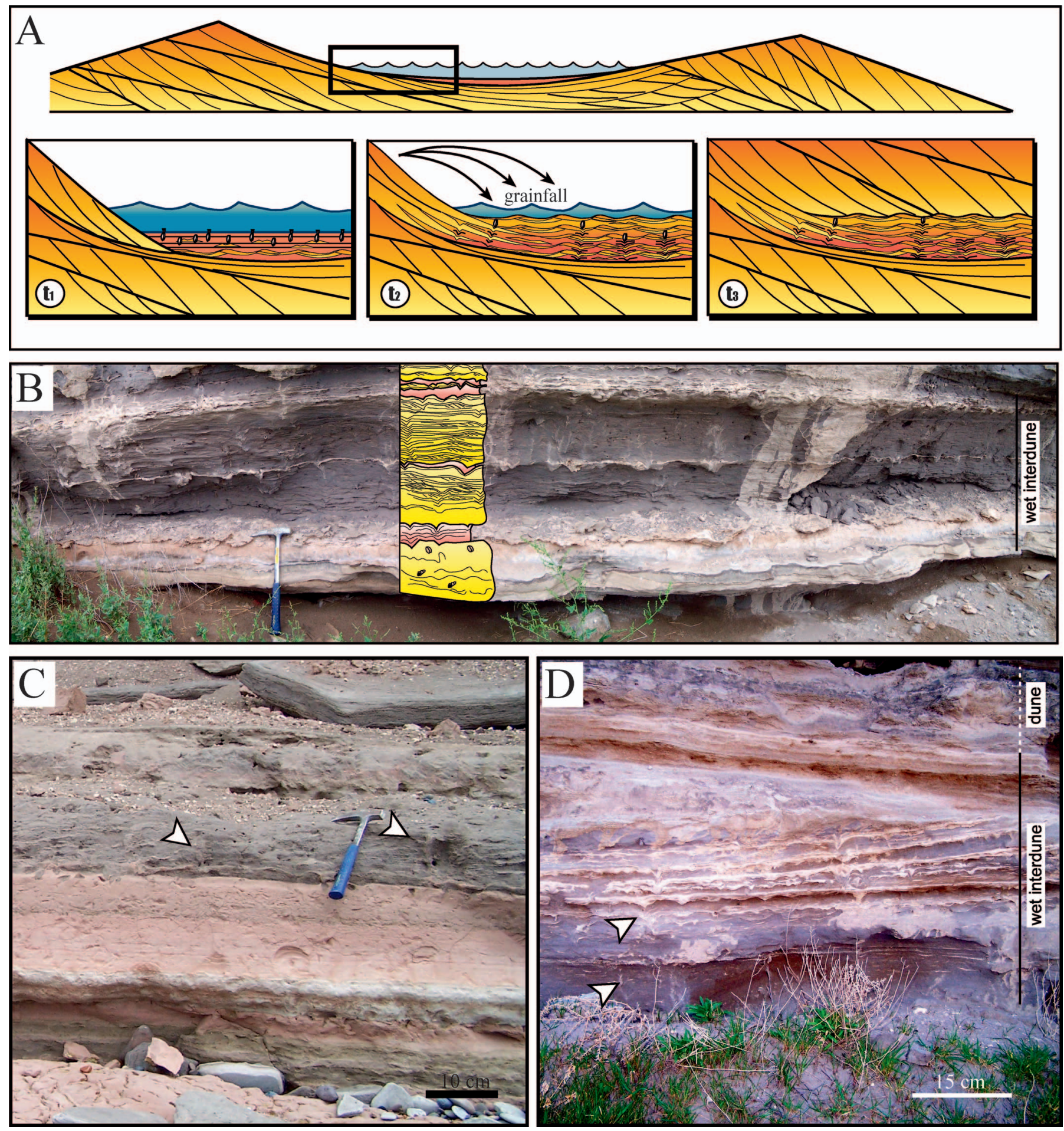

FIG. 5.-Case 2 interpretation: interdune pond with constant or raising water table affected by significant deposition of dune sand. A) Upper scheme showing general configuration of the setting; $t_{1}$ - bivalves colonize muddy heterolithic sediments, $t_{2}$ - bivalves try to escape from burial by producing equilibrium/escape traces when adjacent dunes start to migrate, $t_{3}$ - final stage after complete burial of the wet interdune deposits. B) Field example of Case 2 with schematic representation of the different strata. $\mathbf{C}$, D) Cross-sectional view showing relationship between muddy heterolithic deposits within interdune ponds, covered by sandy heterolithic layers containing equilibrium/escape traces (white arrows) produced by the unioniform bivalves. 
information would be very useful to understand the complex dynamic of coastal dune systems and their evolution through time.

\section{ACKNOWLEDGMENTS}

Financial support for this study was provided by the grants PI-UNRN 2011 40-A158; PICTO-UNRN 2010-0199; PICT 2011-1373; PI-UNRN 2015 40-A-468; PIUNRN 2017 40-A-616 to N. Carmona and J. Ponce, and the Swiss National Science Foundation to A. Wetzel to travel to Argentina (SNF grant 200021-1121128 and 200021_169042/1). The valuable comments provided by the reviewers D. Knaust and A. Ekdale, and the Associate Editor helped us to significantly improve the manuscript. All these contributions are gratefully acknowledged.

\section{REFERENCES}

Alberdi, M.T., Bonadonna, F.P., And Ortiz, E., 1997, Chronological correlation, paleoecology and paleogeography of late Cenozoic South American Rionegran Landmammal fauna: a review: Revista Española de Paleontología, v. 12, p. 249-255.

AмYot, J-P. AND Downing, J.A., 1998, Locomotion of Elliptio complanata (Mollusca: Unionidae): a reproductive function?: Freshwater Biology, v. 39, p. 351-358.

Anderson, L.C., 2014, Ultra-elongate freshwater pearly mussels (Unionida): roles for function and constraint in multiple morphologic convergences with marine taxa, in D.I. Hembree, B.I. Platt, and J.J. Smith (eds.), Experimental Approaches to Understanding Fossil Organisms, Topics in Geobiology 41, p. 21-46.

AndReIs, R.R., 1965, Petrografía y paleocorrientes de la Formación Río Negro (tramo General Conesa - boca del Río Negro): Revista del Museo de La Plata, V, Geología v. 36, p. $245-310$

Aramayo, S.A., 1987, Plohophorus aff. figuratus (Edentata, Glyptodontidae) en la Formación Río Negro (Mioceno tardío-Plioceno), provincia de Río Negro, Argentina; importancia bioestratigráfica: X Congreso Geológico Argentino, San Miguel de Tucumán, v. 3, p. 171-174

Balfour, D.L. AND SMock, L.A, 1995, Distribution, age structure, and movements of the freshwater mussel Elliptio complanata (Mollusca: Unionidae) in a headwater stream: Journal of Freshwater Ecology, v. 10, p. 255-268.

Bogan, A.E. AND RoE, K.J., 2008, Freshwater bivalve (Unioniformes) diversity, systematics, and evolution: status and future directions: Journal of the North American Benthological Society, v. 2, p. 349-369.

Bromley, R.G. And AsgaArd, U., 1979, Triassic freshwater ichnocoenosis from Carlsberg Fjord East Greenland: Palaeogeography, Palaeoclimatology, Palaeoecology, v. 28, p. 39-80.

Carmona, N.B., Ponce, J.J., Wetzel, A., Bournod, C.N., and Cuadrado, D.G., 2012, Microbially induced sedimentary structures in Neogene tidal flats from Argentina: paleoenvironmental, stratigraphic and taphonomic implications: Palaeogeography, Palaeoclimatology, Palaeoecology, v. 353-355, p. 1-9.

Crabaugh, M. and Kocurek, G., 1993, Entrada Sandstone: an example of a wet aeolian system, in K. Pye (ed.), The Dynamics and Environmental Context of Aeolian Sedimentary System: Geological Society Special Publication 72, p. 103-126.

Eriksson, P.G., Porada, H., Baner.ee, S., Bouougri, E., SARkar, S., and Bumby, A.J., 2007, Mat destruction features, in J. Schieber, P.K. Bose, P.G. Eriksson, S. Banerjee, S. Sarkar, W. Altermann, and O. Catuneanu (eds.), Atlas of Microbial Mat Features Preserved within the Clastic Rock Record: Elsevier, Amsterdam, p. 76-105.

Fenton, C.L. And Fenton, M.A., 1937, Burrows and trails from Pennsylvanian rocks if Texas: American Midland Naturalist, v. 18, p. 1079-1084.

Głuszek, A., 1995, Invertebrate trace fossils in the continental deposits of an Upper Carboniferous coal-bearing succession, Upper Silesia, Poland: Studia Geologica Polonica, v. 108 , p. $171-202$.

Good, S.C., 2004, Paleoenvironmental and paleoclimatic significance of freshwater bivalves in the Upper Jurassic Morrison Formation, Western Interior, USA: Sedimentary Geology, v. 167 , p. $163-176$

HaQ, B.U., Hardenbol, J., and VAIL, P.R., 1987, Chronology of fluctuating sea levels since the Triassic (250 million years ago to present): Science, v. 235, p. 1156-1167.

Iglesias, A., Artabe, A.E., And Morel, E.M., 2011, The evolution of Patagonian climate and vegetation from the Mesozoic to the present: Biological Journal of the Linnean Society, v. 103 , p. $409-422$

JAMES, U.P., 1879, Description of new species of fossils and remarks on some others, from the lower and upper Silurian rocks of Ohio: Palaeontologist, v. 3, p. 17-24.

Johnston, P.A. And Hendy, A.J.W., 2005, Paleocology of mollusks from the Upper Cretaceous Belly River Group, in P.J. Currie and E.B. Koppelhus (eds.), Dinosaur Provincial Park, A Spectacular Ancient Ecosystem Revealed: Indiana University Press, Bloomington, p. 139-166.

Knaust, D., 2017, Atlas of Trace Fossils in Well Core, Appearance, Taxonomy and Interpretation: Springer International Publishing, Cham, Switzerland, 209 p. doi: 10.1007/ 978-3-319-49837-9.

Knoll, K., Chamberlain, R.B., and Chamberlain, J.A., JR., 2017, Escape burrowing of modern freshwater bivalves as a paradigm for escape behavior in the Devonian bivalve Archanodon catskillensis: Geosciences, v. 7, p. 102, doi:10.3390/geosciences7040102.

Mángano, M.G., Buatois, L.A., West, R.R., and Maples, C.G., 1998, Contrasting behavioral and feeding strategies recorded by tidal-flat bivalve trace fossils from the Uppe Carboniferous of Eastern Kansas: PALAIOS, v. 13, p. 335-351.
Mángano, M.G., Buatois, L.A., West, R.R., and Maples, C.G., 2002, Ichnology of Pennsylvanian equatorial tidal flat, The Stull Shale Member at Waverly, Eastern Kansas: Kansas Geological Survey, Bulletin 245, 133 p.

MänNIL, R.M., 1966, Notes on the vertical burrowing in the Ordovician limestones of Pribaltica, in Organism and Environment in the Geologic Past: USSR Academy of Science, Palaeontological Institute, p. 200-207.

McMahon, R.F., 1991, Mollusca: Bivalvia, in J.H. Thorp and A.P. Covich (eds.), Ecology and Classification of North American Freshwater Invertebrates: Academic Press, New York, p. 315-399.

McMahon, R.F. and Bogan, A.E., 2001, Chapter 11, Mollusca: Bivalvia, in J.H. Thorp and A.P. Covich (eds.), Ecology and Classification of North American Freshwater Invertebrates, 2nd Edition: Academic Press, San Diego, p. 331-429.

Melchor, R.N., 2009, Bird tracks preserved in fluvial channel facies of the Río Negro Formation (Neogene), La Pampa Province, Argentina: Ameghiniana, v. 46, p. 209-214.

Osgood, R.G., 1970, Trace fossils of the Cincinnati area: Palaeontographica Americana, v. 6, p. 281-444.

Pieńkowski, G. And Uchman, A., 2009, Ptychoplasma conica isp. nov- - a new bivalve locomotion trace fossil from the Lower Jurassic (Hettangian) alluvial sediments of Soltyków, Holy Cross Mountains, Poland: Geological Quarterly, v. 53, p. 397-406.

PličKa, M. And Uhroví, J., 1990, New trace fossils from the Outer Carpathian flysch (Czechoslovakia): Acta Musei Moraviae, Scientiae Naturales, v. 75, p. 53-59.

Rindsberg, A.K., 1994, Ichnology of the Upper Mississippian Hartselle Sandstone of Alabama, with notes on other Carboniferous Formations: Geological Survey of Alabama Bulletin, no. 158, p. 1-107.

SAARINEn, M. And TASKInEN, J., 2003, Burrowing and crawling behavior of three species of Unionidae in Finland: Journal of Molluscan Studies, v. 69, p. 81-86, https://doi.org/10.10 93/mollus/69.1.81.

Schwalb, A.N. and Pusch, M.T., 2007, Horizontal and vertical movements of unionid mussels in a lowland river: Journal of the North American Benthological Society, v. 26, p. 261-272.

SeIlacher, A., 1953, Studien zur Palichnologie, II, Die fossilien Ruhespuren (Cubichnia): Neues Jahrbuch für Geologie und Palaöntologie, Abhandlungen, v. 98, p. 87-124.

SeIlacher, A., 1982, Adaptational strategies of bivalves living as infaunal secondary soft bottom dwellers: Neues Jahrbuch für Geologie und Palaöntologie Abhandlungen, v. 164, p. 229-244.

SeIlacher, A., 1984, Constructional morphology of bivalves: evolutionary pathways in primary versus secondary soft-bottom dwellers: Palaeontology, v. 27, p. 207-237.

STANLEY, S.M., 1968, Post-Paleozoic adaptative radiation of infaunal bivalve molluscs - a consequence of mantle fusion and siphon formation: Journal of Paleontology, v. 42, p. 214-229.

Stanley, S.M., 1970, Relation of shell form to life habits of the Bivalvia (Mollusca): Geological Society of America Memoir, v. 25, p. 1-269.

StanLey, S.M., 1972, Functional morphology and evolution of bysally attached bivalve mollusks: Journal of Paleontology, v. 46, p. 165-212.

ThOms, R.E. AND Berg, T.M., 1985, Interpretation of bivalve trace fossils in fluvial beds of the basal Catskill Formation (Late Devonian), eastern U.S.A., in H.A. Curran (ed.), Biogenic Structures: Their Use in Interpreting Depositional Environments: Society of Economic Paleontologists and Mineralogists Special Publication 35, p. 13-20.

Trueman, E.R., 1968, The locomotion of the freshwater clam Margaritifera margaritifera (Unionacea, Margaritanidae): Malacologia, v. 6, p. 401-410.

Uchman, A., Mikulás, R., And Rindsberg, A.K., 2011, Mollusc trace fossils Ptychoplasma Fenton and Fenton, 1937 and Oravaichnium Plićka and Uhrová, 1990: their type material and ichnospecies: Geobios, v. 44, p. 387-397.

Vaughn, C.C. And Hakenkamp, C.C., 2001, The functional role of burrowing bivalves in freshwater ecosystems: Freshwater Biology, v. 46, p. 1431-1446.

WATtERS, G.T., 1994, Form and function of unionoidean shell sculpture and shape (Bivalvia): American Malacological Bulletin, v. 11, p. 1-20.

Watters, G.T., O'Dee, S.H., And Chordas III, S., 2001, Patterns of vertical migration in freshwater mussels (Bivalvia: Unionoida): Journal of Freshwater Ecology, v. 16, p. 541549

Zachos, J., Pagani, M., Sloan, L., Thomas, E., and Billups, K., 2001, Trends, rhythms, and aberrations in global climate 65 Ma to present: Science, v. 292, p. 686-693.

Zavala, C. AND FreiJe, H., 2000, Estratigrafía secuencial del Terciario superior marino de Patagonia, un equivalente de la "crisis del Messiniano"?: Revista Geotemas, Sociedad Geológica de España, v. 1, p. 217-221.

Zavala, C. And FreiJe, H., 2001, On the understanding of Aeolian sequence stratigraphy: an example from Miocene-Pliocene deposits un Patagonia, Argentina: Rivista Italiana di Paleontologia e Stratigrafia: v. 107, p. 251-264

Zavala, C., Abrameto, A., Azúa, G., Freije, H., Inchentronn, C., and Ponce, J.J., 2000, Estratigrafía de los acantilados marinos de la zona de El Cóndor-Bahía Rosa (Formación Río Negro, Mioceno-Plioceno): Provincia de Río Negro, II Congreso Latinoamericano de Sedimentología, Resúmenes, p. 186-187.

Zinsmeister, W.J., Marshall, L.G., Drake, R.E., and Curtis, G.H., 1981, First radioisotope (Potassium-Argon) age of marine Neogene Rio Negro beds in northeastern Patagonia, Argentina: Science, v. 214, p. 440.

Received 28 March 2018; accepted 3 July 2018. 